\title{
TAKAFUL RETIREMENT ANNUITY PLAN IN MALAYSIA: A PROPOSED MODEL
}

\author{
Mohammad Mahbubi Ali* \\ Lokmanulhakim Hussain** \\ Faisal Haroon Zai***
}

\begin{abstract}
Islamic insurance, hereafter referred to as takaful, is established on the concept of mutual assistance and mutual assurance between participating members who undertake to mutually guarantee and indemnify one another in case of a particular defined event. This concept has been widely used to structure various takaful products, ranging from general to family takaful, with features that resemble most of the features of conventional insurance. Nevertheless, the fact remains that not all conventional product features can be easily adopted and offered by takaful operators (TOs). This is evident in the absence of a Shari'ah-compliant model for retirement annuity plans with defined benefit features in the Malaysian takaful industry. This is despite its important features of providing security and peace of mind to the participants during their retirement years. The present study proposes the application of a hibah mu'allaqah (conditional gift) contract structured together with a wakalah (agency) contract for a Shari'ah-compliant retirement annuity plan. The study also identifies several potential Shari'ah issues and operational challenges entangling the proposed model. The study concludes with a set of policy recommendations.
\end{abstract}

Keywords: annuity, longevity risk, hibah mu'allaqah, gharar, maysir.

\section{Introduction}

Conventional insurance, despite its noble objective of providing a risk management instrument and offering "peace of mind", is prohibited by the Shari'ah as it is an exchange contract that contains substantial uncertainty (gharar) as well as elements of gambling and riba (interest). On the other hand, the Islamic alternative to conventional insurance, known as takaful, is established on the notion of mutual assistance (ta 'awun), mutual security and guarantee (tadhamun) and mutual protection and assurance (takaful) between participants on the basis of brotherhood, deeply rooted in the concept of charitable donation (tabarru'), which tolerates the presence of jahalah (ignorance) and gharar (uncertainty). 
These basic principles underlying the takaful contract have been extensively used to structure various products, ranging from a general takaful to a family takaful, with features that resemble those of conventional insurance products. Notwithstanding this, the fact remains that not all features and characteristics of conventional insurance can be easily adopted and offered by takaful operators. This is particularly true with regard to the absence of a Shari'ah-compliant retirement annuity plan in the Malaysian takaful industry.

Against this backdrop, this study undertakes to achieve the following research objectives:

1. To understand the concept and practice of the retirement annuity plan in conventional insurance.

2. To identify Shari'ah and operational issues facing the takaful industry in developing a Shari'ah-compliant retirement annuity plan.

3. To propose a Shari'ah-compliant model for a retirement annuity plan.

This study is organised according to the following structure: section two briefly discusses the concept of the conventional retirement annuity plan. Section three proposes a Shari'ah-compliant structure for the retirement annuity plan with features resembling those of conventional insurance. Section four identifies some potential Shari'ah issues surrounding the proposed structure as well as operational issues in developing a Shari'ah-compliant retirement annuity plan. The last section concludes the study.

\section{The Conventional Retirement Annuity Plan}

The word annuity is derived from annulus, the Latin word for annual, and is defined as a financial investment which entitles the annuitant to receive a series of regular pay-outs as a defined benefit, commonly for the rest of the annuitant's life. $^{2}$ It is a retirement-based insurance product which provides a series of regular payments to an annuitant in exchange for either a single contribution or a series of regular contributions prior to the start of the annuity payments.

Generally, there are two types of retirement products available in the market: income drawdown and annuity. Income drawdown allows annuitants to convert their savings to a regular stream of income for a certain fixed period of time. In this product, the annuitants receive the regular income up to the maximum total of their accumulated savings. In the event of early death, the remaining savings are transferred to their nominees or legal heirs. ${ }^{3}$

On the other hand, an annuity allows annuitants to convert their savings into a regular stream of income for the rest of an annuitant's life. Annuity is generally designed to pay a regular fixed amount until the annuitant's death. The purpose 
of annuities is mainly to provide income and consumption smoothing after retirement by ensuring a regular stream of payouts over the rest of the annuitant's life. Therefore, despite some variations in the market, the annuity contract generally expires at the point of the annuitant's death, and no further payment is provided thereafter. For example, if the annuitant dies after receiving just one annuity payment, the dependents have no claim upon the remaining savings used to buy the annuity. The main benefit of an annuity is that the risk of living beyond one's savings is transferred to the insurer.

Typically, annuity products are classified into three types: ${ }^{4}$

1. Single life: Under this type, the annuitants will receive a regular stream of income for as long as they live. The payments cease and the contract ends when an annuitant dies.

2. Joint-life annuity: Under this type, annuitant couples jointly receive a regular income for the rest of their lives. The payout will cease should one of them die.

3. Joint-survivor annuity: Under this type, annuitant couples jointly receive a regular income for the rest of their lives. Unlike joint-life annuity, the payment will continue after the death of the first partner, although it is usually reduced, until the demise of the second annuitant. In the symmetric joint-life survivor annuity, the amount of payment will be equal regardless of which spouse survives. On the other hand, in the contingent joint-life survivor annuity, payment to one life, i.e., the second one, may be lower than to the other.

Despite the variations in the annuity products in the market, Figure 1 illustrates the basic design of typical regular contributions to a conventional retirement annuity product structure:

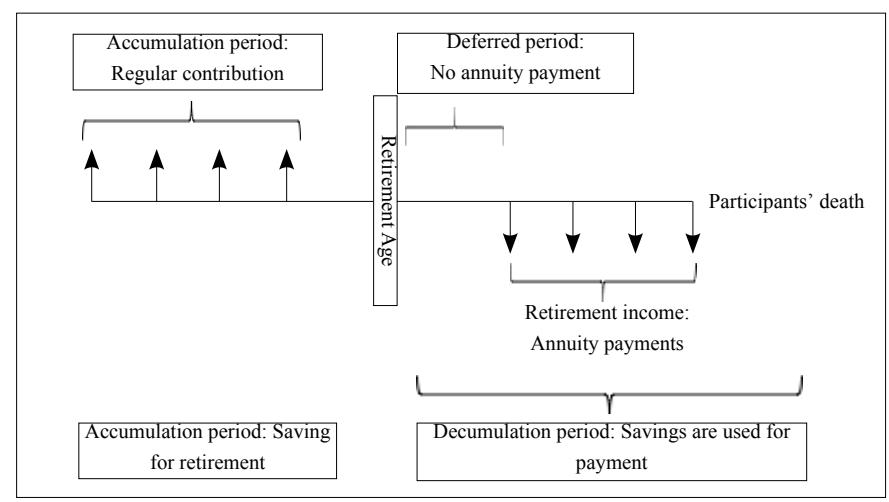

Figure 1: Structure of Conventional Retirement Annuity Plan 
In the above structure, the annuity product is divided into an accumulation period and a decumulation period. During the accumulation period, annuitants contribute their funds as savings to allow them to receive regular income after retirement. Should the annuitants die during this period, the accumulated savings plus its return will be distributed to their legal heirs or nominees. During the decumulation period, the annuitants reach retirement age. This period usually consists of a deferred period and a payment period.

During the deferred period after retirement, no annuity payments are provided to the annuitants. If the annuitants die during this period, the accumulated savings and their returns are transferred to their legal heirs or nominees. The reason for establishing a deferred period is that it allows the insurer to fully invest the accumulated money before payment starts. This will enable the insurer to manage the pricing issue. Usually the price for the annuity plan with a deferred period is cheaper than that without a deferred period. The payment period will start after the deferred period ends. The annuity payment, despite some variations in the market, is generally provided for the rest of each annuitant's life. If an annuitant dies early, the payment will cease and no further payments to their legal heirs or nominees will be provided. Box 1 provides a simple illustration of the conventional retirement annuity product (numbers are purely illustrative):

\begin{tabular}{|lll|}
\hline Accumulated savings & $:$ & RM100,000 \\
Retirement age & $:$ & 55 \\
Deferred period & $:$ & 5 years \\
Monthly payment & $:$ & RM 1,500 \\
Annuitant's lifespan & $:$ & 76 years \\
Total payment received & $:$ & 288,000 \\
& & \\
\hline
\end{tabular}

Box 1: Illustration of a Conventional Retirement Annuity Plan

\section{Proposed Takaful Retirement Annuity Plan Structure}

The current conventional retirement annuity scheme offers the noble objective of providing income and consumption smoothing for the annuitants after their retirement. Nevertheless, its structure contains a number of Shari'ah prohibitions revolving around the contract of exchange (mu'awadah), which attracts the issue of riba, uncertainty and gambling. The issue of riba, for example, emerges in two forms. Firstly, the conventional retirement plan is the exchange of money for money in unequal amounts and on a deferred basis. This is so since the 
defined benefit that the annuitant will receive may be higher or lower than the accumulated savings and is contingent upon a future defined event. Secondly, the accumulated saving is invested in interest bearing instruments, such as treasury bills and fixed deposits in conventional banks. The feature of uncertainty, on the other hand, occurs in conventional insurance because both the right to the defined benefit and its actual value are dependent upon the occurrence of death, which is uncertain. ${ }^{3}$ As for gambling, this occurs in conventional retirement plans as a consequence of the aforementioned uncertainty, where the gain or loss is contingent on the period of regular payout.

Against the above backdrop, this paper proposes a Shari'ah-compliant model for a takaful retirement annuity plan that can deliver similar benefits as the conventional retirement annuity plan. The proposed model is based on a hibah mu 'allaqah (conditional gift) contract to be structured together with a wakalah (agency) contract. The following subsection, therefore, discusses the concept of hibah mu'allaqah to provide a clear understanding about the proposed takaful retirement annuity plan.

\section{The Concept of Hibah Mu'allaqah}

Hibah mu'allaqah is a form of gift, the effectiveness of which is contingent upon fulfilment of a certain condition or event in the future. In this regard, hibah becomes effective when the stipulated condition is satisfied. ${ }^{5}$

There are two major views among classical jurists on hibah mu'allaqah; namely those who deem it a valid contract and those who consider it invalid.

The Maliki school of thought and some jurists from the Hanbali school of thought such as Ibn Taymiyyah and his disciple, Ibn al-Qayyim, allow and validate hibah mu'allaqah.

This view is based on the following evidence and arguments:

a. The hadith of Jabir:

Jabir reported: The Prophet (pbuh) said to me, "When the revenues of Bahrain arrive, I shall give you such, and such, and such." He passed away before the revenues were received. When they arrived during the caliphate of Abu Bakr, he (Abu Bakr) ordered it to be announced: "Anyone whom the Messenger of Allah (pbuh) promised or owed anything should come to us." I went to him and said: "The Messenger of Allah (pbuh) told me such and such." He took a double handful out of the money and gave it to me. I counted it and found that it was five hundred dirhams. Then Abu Bakr said to me: "Take twice as much more of that amount." 
b. The hadith of Umm Kulthum

Umm Kulthum bint Abi Salamah reported that when the Prophet (pbuh) married Umm Salamah, he said to her, "I gave al-Najashi gifts, a hullah (a kind of garment) and some musk, but now I am quite sure that he just died, and I believe that my gifts will be returned to me. If the gifts are returned to me, then they will be yours." Umm Kulthum continued: "It turned out as the Messenger of Allah (pbuh) said it would, and the gifts were returned. He gave every one of his wives some of the musk and gave Umm Salamah the rest of the musk and the garment."7

c. Hibah is given at the sole discretion of the donor. Therefore, he has the full right to give hibah in whatever manner he likes as long as it is in accordance with Shari'ah principles and free from any prohibited element. ${ }^{8}$

d. The original ruling in every contract is of permissibility and there is no clear evidence to negate the legitimacy of hibah mu'allaqah.

e. Hibah is a form of unilateral contract where, unlike in an exchange contract, the element of uncertainty is tolerated. The difference between the two is that an exchange contract is legislated with the recognition that each party is seeking to maximise his personal interest; thus the element of uncertainty is likely to harm one of the parties. On the other hand, hibah is intended for charitable purposes, which means that the element of uncertainty would not harm the recipient. ${ }^{9}$

On the other hand, the opinion of the Hanafi, Shafi'i and Zahiri schools, in additon to the dominant opinion of the Hanbali school, is that conditional hibah is invalid. The central basis of this view lies in the definition of hibah as a transfer of ownership and the view that a transfer of ownership takes immediate effect upon its execution. The implications of that view are then detailed in the following evidence and arguments:

a. Hibah is a transfer of ownership that takes immediate effect. Thus, it shall not be made contingent upon a future event because the element of ignorance (jahalah) negates its validity ${ }^{10}$ and causes the contract to be classified under the rubric of uncertain contracts ('uqud gharar), which have been prohibited by the Prophet (pbuh). ${ }^{11}$

b. Hibah which is left pending upon fulfilment of certain conditions violates the inherent nature and implications of the hibah contract (muqtadha al'aqd) by including elements of gambling. ${ }^{12}$ 
c. Ibn Qudamah of the Hanbali school employed qiyas (legal analogy), arguing that, because hibah, like a sale contract, transfers ownership, it therefore cannot be left pending upon a condition, just as such a condition is not allowed in a sale contract. ${ }^{13}$

d. Some scholars from the Hanbali school gave a counter-interpretation of the statement of the Prophet (pbuh) in the hadith of Umm Kulthum, "If the gifts are returned to me, then they will be yours." They argued that it does not signify hibah mu'allaqah but, rather, a promise. ${ }^{14}$

For the purpose of this structure the view which allows and validates hibah mu'allaqah is adopted. Hibah mu'allaqah is also approved by the Accounting and Auditing Organization for Islamic Financial Institutions (AAOIFI) in its Shari'ah Standard (2015) no. 46 on wakalah bi al-istithmar and by the Bank Negara Malaysia in its Shari'ah Standard (2017) on hibah.

\section{Structuring Takaful Retirement Annuity Plans Based on Hibah Mu'allaqah}

Based on the definition and characteristics of hibah mu'allaqah, the authors are of the opinion that this contract, together with a wakalah (agency) contract, is suitable for structuring a takaful retirement annuity plan with features that resemble those of conventional annuity based on the following considerations:

1. The application of a hibah contract allows the guaranteeing of an income stream of regular payouts to the participants after their retirement.

2. Hibah mu 'allaqah allows the participants to enter into a hibah contract at the first stage for the purpose of establishing a tabarru' fund at the later stage.

3. A wakalah contract is employed to allow the takaful operator (TO) to manage the plan and invest the funds.

It is worth noting that there are two variations in the market with regards to the decumulation period. Some practices apply a deferred period before the payout starts while others provide payout immediately upon retirement age. This variation will normally affect the pricing and payout. The plan with a deferred period commonly offers a lower regular contribution or a higher payout. In contrast, the plan with no deferred period will have a higher regular contribution or a lower payout. Figure 2 below illustrates the proposed takaful retirement annuity plan with a deferred period. Figure 3 depicts the model with no deferred period. 


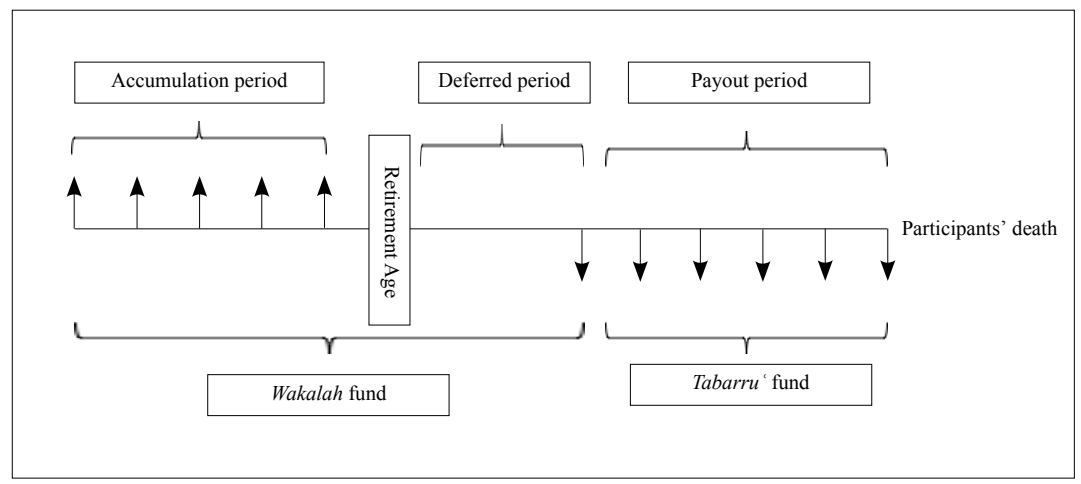

Figure 2: Proposed Takaful Retirement Annuity Plan with a Deferred Period

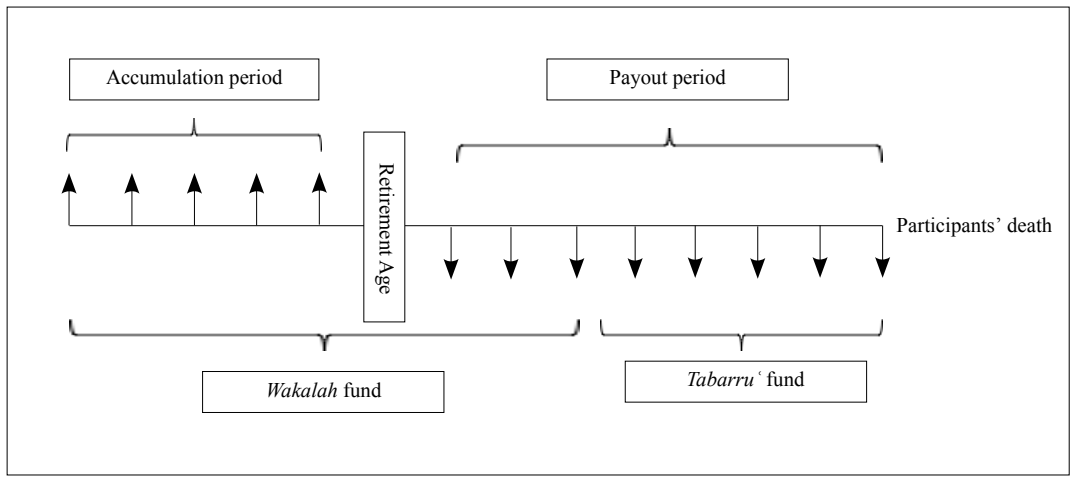

Figure 3: Proposed Takaful Retirement Annuity Plan with No Deferred Period

1. Participants agree to enter into a wakalah contract with a takaful operator (TO). At this stage, the participants appoint the TO as an agent (wakil) to manage the plan and invest the funds. As an agent, it will receive an agreed pre-determined fixed wakalah fee.

2. Under the wakalah contract, the participants then make the investment contribution that is to be managed by the TO. In case a participant withdraws his investment contributions during the accumulation period, he/she will receive the total accumulated investment amount together with its return.

3. Immediately, the participants agree to enter into the contract of hibah mu'allaqah, whereby they will donate the accumulated investment fund together with its profit into the tabarru' fund upon retirement age or upon expiry of the deferred period (if any). At this stage, the TO is appointed 
by the participants as an agent to manage the tabarru' funds with certain fees.

4. The participants also agree that those participants whose funds have been transferred into the tabarru' fund are entitled to enjoy financial benefit from that fund in the form of regular payouts from the end of the deferred period until death.

5. The payouts start after the retirement age or the deferred period (if any). The payouts cease upon the demise of the participant.

6. In case a participant dies during the deferred period (if any), the accumulated contribution and its return will be transferred to his/her legal heirs or nominees.

Based on the above structure, it can be concluded that the contractual relationship among the participants is based on a partnership contract to collectively contribute money to the investment fund and tabarru' fund. The contractual relationship between the participants and TO is based on an agency contract, whereby the TO is mandated to manage the investment funds and tabarru' funds. Meanwhile, the contractual relationship between the participants and the funds is based on a hibah commitment at the accumulation stage and the indemnification commitment at the payout stage. ${ }^{15}$

Table 1 provides a simple calculation of the pricing and payout of the proposed structure, both with a deferred period (DP) and without a DP.

\begin{tabular}{|l|c|c|}
\hline & Without DP & With DP \\
\hline $\begin{array}{l}\text { Total annuity contribution at } \\
\text { retirement (RM) }\end{array}$ & RM 100,000 & RM 100,000 \\
\hline Retirement age & 60 & 60 \\
\hline Deferment period & 10 years & - \\
\hline Expected age at death & 80 & 80 \\
\hline Annuity starts at age & 70 & 60 \\
\hline Annuity paid for & 10 years & 20 years \\
\hline $\begin{array}{l}\text { Estimated annual annuity payout } \\
\text { (RM) }\end{array}$ & 8,000 & 3,000 \\
\hline
\end{tabular}

Table 1: Pricing and Payout of the Proposed Structure 
As depicted in Figures 2 and 3, the model provides features similar to the conventional annuity plan. The hibah mu'allaqah model allows TOs to guarantee regular payout to the participants without, in any way, violating the priciples of Shari'ah. The model also allows the participants to convert their money from the investment funds into the tabarru' funds. Notwithstanding that, the plan may have some other features and variations; for instance:

1. The plan may offer both a single contribution option and a regular contribution option. Those who opt for a single contribution may be entitled to a cheaper total contribution as opposed to those who opt for a series of regular contributions. From the perspective of the TOs, they would prefer offering the regular contribution option as they can charge investment expenses.

2. The plan may be structured in such a way that the participants transfer only a certain percentage of their wakalah fund into the tabarru' fund, e.g., $70 \%$. The remaining balance of $30 \%$ would still belong to the participants and would be treated as the wakalah fund. This feature would enable their dependents or legal heirs to be entitled to the remaining balance $(30 \%)$ in case the participants die after their retirement. However, this feature would normally affect the price and payout mechanism, i.e., the contribution would be higher or the payout would be lower.

\section{Shari'ah Issues in the Proposed Takaful Retirement Annuity Plan}

The Shari'ah aspect is the most crucial part in developing any Islamic financial product. The proposed Shari'ah-compliant model for retirement annuity plans should be free from any contentious Shari'ah issues. Therefore, any potential Shari'ah issues which may raise questions about the validity of the underlying contract must be prudently identified and examined. This section addresses several potential Shari'ah issues surrounding the proposed hibah mu 'allaqah model, namely the issue of riba (which revolves around the inherent nature of hibah al-thawab), the element of gharar, elements of gambling, and the issue of the defined event.

\section{The Issue of Hibah al-thawab (Gift for Consideration)}

Ibn 'Arafat defines hibah al-thawab as:

A gift for which financial compensation is intended. ${ }^{16}$

The author of Sharh Kifayat al-Thalib defines it as:

One person gives his asset to another so that he will give him consideration for it. ${ }^{17}$ 
From the two definitions above, it is understood that hibah al-thawab is a gift given by one person to another with the intention of eliciting compensation from the latter.

Hibah is basically a form of tabarru' contract which is charitable rather than profit orientated. When hibah is given with the condition of consideration, therefore, Muslim jurists are divided into two major views concerning it.

The first view considers a gift with consideration as valid (sahih) and effective (nafidh). This view is held by the majority of Hanafi, Maliki, Shafi'i and Hanbali jurists. ${ }^{18}$ The second opinion, which is narrated as one view in the Shafi'i school, is that this kind of hibah is null and void. ${ }^{19}$

Although the majority of scholars consider hibah al-thawab to be a valid contract, the overwhelming majority who hold that view are of the opinion that its essential nature has been transformed so it no longer has the ruling of hibah; rather, its characteristics resemble that of a mu'awadah (exchange) contract, i.e., it is a sale. The second opinion is that hibah al-thawab remains as hibah with all its Shari'ah implications. In this view, the status of hibah al-thawab does not change in any way from hibah to an exchange contract. A narration in the Hanbali school of thought, as quoted by Ibn Qudamah, states:

A (second) narration from Ahmad (ibn Hanbal) implies that the ruling of hibah in hibah mu'allaqah prevails (over the ruling of exchange contract). Therefore, the rulings specific to sale contracts do not apply to it. ${ }^{20}$

Al-Mardawi cites al-Qadi's view, stating:

(Hibat al-thawab) is not a sale contract because hibah may sometimes be given purely as charity and may sometimes be given for a consideration. ${ }^{21}$

Al-Sharbini quoted two views from the Shafi'i school regarding one who gives hibah that requires an unknown consideration. One of the views states that this form of hibah is valid as hibah, not as bay ' (sale). ${ }^{22}$

The issue of hibat al-thawab emerges in the proposed structure in that the participants who donate their funds stipulate a condition to enjoy the benefit of their donation in the form of periodic payments during their lifetime after the retirement age.

If we consider the first view that regards the ruling of hibat al-thawab as being similar to that of an exchange contract (mu'awadah), it will attract the issue of riba al-fadl (the exchange of money for money in unequal amounts). This is because the benefit that the participants receive in the form of regular payouts may be substantially higher or lower than the actual amount contributed. It may also trigger the issue of riba al-nasi'ah in that the exchange of money is not done 
on the spot; it is deferred. However, if we adopt the second view, that hibah althawab remains a hibah contract, the issue of riba does not apply.

For the purpose of this proposed structure, the second view is adopted. Although the latter view is upheld by a minority of jurists, it is regarded as sound and strong in Islamic jurisprudence (fiqh). Al-Mardawi cites al-Harithi's opinion that this view is stronger than the former view:

Al-Harithi said: "This view (that hibah al-thawab is not a sale contract) is authentic, and it is very sound." He said regarding the first (view): "It is very weak." ${ }^{23}$

Adopting the view that hibat al-thawab remains hibah means that the issues of both riba al-fadl and riba al-nasi'ah in the proposed structure are resolved. This is in line with the legal maxim that "...riba exists in mu'awadat contracts and is not applicable in the hibah contract since it is considered a form of tabarru '."24

\section{The Issue of Gharar (Uncertainty)}

Gharar refers to uncertainty in a transaction. The element of gharar in a mu'awadah contract affects the validity of the transaction. On the other hand, the element of gharar in a tabarru ' contract is disputed among jurists. Some scholars argue that gharar and jahalah (ignorance) affect the validity of tabarru'at contracts such as hibah and sadaqah while others take the opposite view. ${ }^{25}$

In the context of hibah in particular, the Hanafi, Shafi'i and Hanbali schools are of the opinion that the element of gharar invalidates a hibah contract just as it does a typical sale contract. ${ }^{26}$ In contrast, the Maliki school is of the view that the existence of gharar in hibah does not affect the validity of the contract:

There is no dispute in the Maliki school regarding the permissibility of hibah that is unknown or that does not exist yet but is expected to exist. In general, everything that is invalid to sell in the Shari'ah due to the existence of uncertainty [is permissible in hibah]. ${ }^{27}$

The Maliki view is premised on the grounds that hibah is given for a charitable purpose so the feature of uncertainty would not harm the other party. In contrast, the element of uncertainty in an exchange contract is likely to harm at least one of the parties as the intent of each party is to maximise its own benefit from the exchange. ${ }^{28}$ The element of uncertainty in the proposed structure is said to exist in the form of the total amount of payments received by the participants. As the annuity plan is intended to provide a regular stream of income to participants starting from the retirement age until the death, the total amount to be paid by the TO cannot be precisely determined as it all depends on the participants' lifespans. 
Those who live longer will receive higher amounts than those who live for a shorter period. They may also enjoy a payment higher than the total contribution they accumulated.

Nevertheless, after reviewing the definition of uncertainty and the debate about it among scholars, this study takes the stand that the issue of prohibited uncertainty is not applicable to the proposed structure. This is due to the following factors:

1. The study adopts the view that the element of uncertainty does not affect the validity of a hibah contract. This is because hibah is a charitable contract which tolerates the element of uncertainty. This opinion, although it is held by a minority, is regarded as an established opinion in Islamic jurisprudence and is supported by the Maliki school.

2. The view which tolerates the element of uncertainty in a hibah contract is also supported by the Accounting and Auditing Organization for Islamic Financial Institutions (AAOIFI), a well-known international contemporary standard-issuing body that has issued a standard (standard no. 46) on wakalah bi al-istithmar, which basically allows the use of hibah mu'allaqah (which contains the element of uncertainty) for the purpose of giving a hafiz (incentive) to the investment agent.

\section{The Issue of Gambling}

Qimar refers to an act of betting one's asset in order to acquire another person's asset, either through competition, conditional games or other means. The proposed structure may attract the issue of gambling because the level of benefits enjoyed by the participants varies depending on their lifespan. In fact, some of them may receive nothing or substantially less than what they have accumulated. For instance, a participant who dies after the deferred period has lapsed but before receiving any periodic payments from the TO will have suffered a total loss as their legal heirs do not receive any consideration from his contributions, assuming that he has transferred all wakalah funds to the tabarru' account. On the other hand, if he lives longer, he would receive a series of regular payments which may total substantially higher than the amount he contributed. Further, if the participant dies before reaching the retirement age, the nominee or the beneficiary will receive the principal amount plus profit. Therefore, four scenarios may arise in the annuity product:

1. A participant dies or surrenders before the retirement age; the nominee or beneficiary will receive the accumulated investment principal together with its associated profit share. 
2. A participant reaches the retirement age and dies during the deferred period; the nominees or beneficiaries will receive all the accumulated funds.

3. A participant dies after the retirement age or after the deferred period (if any), but he dies before enjoying any payout. In this scenario, his nominee or beneficiary will receive nothing. In other words, he suffers a total loss.

4. A participant lives long and receives benefit from periodic payments until death, such that the amount of payout received is substantially higher than the amount he contributed. In this scenario, he gains.

In the situations above, the element of gambling prohibited by the Shari'ah exists in conventional retirement annuity schemes because the gain or loss is tied to a specific uncertain event, namely the participant's death. However, the proposed takaful retirement annuity plan based on hibah mu allaqah cannot be dealt with by a similar ruling to the conventional annuity although it resembles the latter's features. This is because the proposed retirement annuity structure is designed based on different Shari'ah contracts which allow certain features of the conventional annuity to be adopted in a Shari'ah-compliant context. If we refer to the proposed Shari'ah structure above, it is obvious that the element of gambling does not exist as it does not actually fit the characteristics of gambling (qimar) prohibited by the Shari'ah.

The possible scenarios associated with the annuity structure are worth reviewing when deliberating this issue. In case the participant dies before the retirement age, the nominee or the participant's heirs are entitled to the entire contribution and its profit. In this period, the relationship between participants and the TO is of a principal-investment agent relationship. Hence, the money accumulated from the fund during this period, both principal and profit, belongs entirely to the participants. Thus, if a participant dies, the fund is returned to the nominees or legal heirs. However, if a participant dies after the retirement age or after the deferred period (if any), all money in the fund is no longer owned by the participants since they have already made a tabarru' contract via hibah mu 'allaqah at the time the contract was executed. In fact, even when a participant dies after the deferred period lapses but before receiving any benefit or payment from the annuity, it does not mean he/she suffers total loss. That is because, after this period, the fund he/she invested in goes to the tabarru ' fund, which is intended to mutually assist other participants.

On the other hand, in case when the participant survives, he will be entitled to enjoy the benefit in the form of a series of payments from the tabarru 'fund to which he contributed. The right to the financial benefit is based on the mutually 
agreed condition at the time the hibah contract was executed to eventually benefit from donations. Hence the periodic payment the participant receives cannot be considered as a gain at the expense of others; rather, it is made to meet the conditions mutually agreed by all participants. The TO has a responsibility to explain clearly to all potential participants the possible scenarios and the reason why the charitable element in the structure can resolve the issue of gambling. The participants in the "losing scenario" will not actually be losing if their intention is correct.

\section{The Issue of the Unfortunate Event}

Generally, the contribution made by takaful participants is intended to provide assistance should any participants in the plan experience misfortunes or calamities such as death, permanent disability, accidents, etc. In other words, the contribution is intended to compensate the participants for defined unfortunate events or financial loss in the future. The question which may arise is whether the retirement age in the case of the annuity plan meets the requirements, from the Shari'ah point of view, of a defined unfortunate event, which would qualify it as a "takaful-able" interest. One may argue that the incorporation of the tabarru" concept via hibah mu'allaqah might not be relevant in the retirement annuity plan since the objective of mutual help may not be applicable, given the fact that no element of unfortunate event, risk, peril or hazard has actually occurred in the plan. In other words, the element of mutual help upon the occurrence of an unfortunate event does not actually exist in the plan.

To answer this, it is worth noting that the income for an employee who reaches retirement age will eventually cease, or at least diminish, as he will not receive any monthly salary afterward. Despite that, he needs to survive and bear the expenses of his dependents. Therefore, the doubt that no unfortunate event or defined financial loss exists in the annuity plan is incorrect in most cases. In fact, assuming that the unfortunate event does not arise, the application of tabarru ' in the proposed structure is still relevant and valid from the Shari'ah point of view based on the following justifications:

1. As indicated earlier, the adoption of hibah al-thawab in the proposed structure is not tantamount to riba. It is therefore not required that the consideration in hibah be given contingent upon a defined unfortunate event; rather, it is based on mutual agreement among parties. This corresponds to the legal maxim which reads:

The fundamental (requirement for the validity of a contract) is the consent of the contracting parties, and its effects are the rights and duties they agree to. ${ }^{29}$ 
2. The SAC, in its $102^{\text {nd }}$ meeting in 2010 , resolved that the payment of takaful benefits from tabarru' funds can be made contingent upon specific events beyond those arising from a defined financial loss or a misfortune. This is allowed subject to the agreement of the contracting parties, i.e., the participants. This decision was made in line with a takaful contract that is established based on the concept of tabarru' and ta 'awun. These two concepts allow participants to agree on the events leading to payment of the takaful benefits. Thus, with the agreement from the participants, the scope of events prompting payment of takaful benefits from tabarru funds need not be limited to death, disability or calamity but can also be extended to cover attainment of the contracted mandate such as survival benefit for a retirement and annuity plan, maturity benefit for an education plan, and surrender benefit.

\section{Operational Issues in Developing Takaful Retirement Annuity Plans}

The absence of a Shari'ah-compliant retirement annuity plan is not merely due to the absence of models and structures which enable accommodation of the product in the market. There are also a number of complex operational issues which hinder its development. The following section identifies key operational issues and challenges faced by the takaful industry in developing a Shari'ahcompliant retirement annuity plan.

\section{The Availability of Long-Term Investments}

Since a retirement annuity plan is designed to provide benefit over the long term, there is a need for investment avenues which can offer a regular income stream over a similarly long period. The conventional type of investment that is apparently able to meet these requirements is bonds.

Sukuk, sometimes referred to as an Islamic bond, is an investment instrument which resembles, in most aspects, the characteristics and features of conventional bonds. ${ }^{30}$ However, there are some practical issues which impede investment in sukuk for the purpose offering a regular income stream over the long term. ${ }^{31}$ Most sukuk in the primary market are purchased by large financial companies and banks, which reduces the opportunities for takaful companies to invest in sukuk. Even if takaful companies are able to obtain sukuk from the secondary market, the respective sukuk are mostly expensive and illiquid; hence investing in sukuk through the secondary market will only create loss rather than profit. ${ }^{32}$

Besides that, the availability of sukuk, long-term sukuk in particular, is limited. According to Thomson Reuters, there are only 33 sukuk with a maturity of 20-50 years currently available in the market. The rest are short-term and medium- 
term sukuk; 189 sukuk have a maturity of less than one year; 1134 sukuk have a maturity of 1-9 years; and 302 sukuk have a maturity of 10-19 years. On the conventional side, there are approximately 7,093 bonds with tenures between 20 and 50 years. Without sufficient long-term investments, annuity products would require huge capital. Thus, the limited availability of long-term sukuk to facilitate annuity products is one of the main challenges and obstacles in developing a takaful retirement annuity plan.

One of the proposed solutions to address limited sukuk availability is to support Shari'ah-compliant retirement annuities with real assets, e.g., equities, properties and precious metals. However, these types of investment are characterised with high price volatility, which does not match the need and nature of annuities to provide a regular fixed income stream. ${ }^{33}$ Another solution, as proposed by the Milliman Pension Takaful Report, is to provide longevity sukuk. This type of sukuk may address the issue of longevity risk facing most annuity products. ${ }^{34}$

\section{Frequency of the Sukuk Coupon}

According to the data from Thomson Reuters, the coupons (in the form of rental fee or profit sharing) for long-term sukuk (20 years and above) in the market are distributed semi-annually (every six months). In contrast, the coupons for long-term bonds are issued quarterly or even monthly. For instance, out of 37 bonds issued with a tenure of 40 years, there is 1 bond whose coupon is distributed every month; 5 whose coupons are issued quarterly; 10 whose coupons are given semi-annually; and 1 whose coupon is issued annually. ${ }^{35}$ Thus, conventional annuity products have various options for more frequent income streams within a year while a takaful retirement annuity would face less liquidity as it could only earn a semi-annual income stream. This fact will certainly lead to mismatch and liquidity issues as the annuity requires a regular fixed income stream, commonly on a monthly basis.

\section{Longevity Risk}

Longevity risk is defined as the risk of unanticipated increases in life expectancy. ${ }^{36}$ In the case of a retirement annuity plan, longevity risk arises when the contributor or participant lives longer than the estimated age limit. This risk raises the spectre of financial inadequacy since the annuity company has to constantly support the participants until their deaths. ${ }^{37}$ The United Nations (UN) indicated that the aging population has undergone significant increase from year to year throughout the world. According to a UN report (2013), the population segment aged 60 and above is the fastest growing population segment in the world. It is expected that this number will triple by 2100 , i.e., from 900 million in 2015 to 2.1 billion in 2050, and 3.2 billion by 2100 . 
In line with the world's ageing population as projected by the UN, the population aged 65 and above in Malaysia is estimated to more than double by 2040 . Table 2 below illustrates the projected Malaysian population based on age.

\begin{tabular}{|c|c|c|c|c|c|c|c|}
\hline Year & $\begin{array}{c}\mathbf{0 - 1 4} \\
(\mathbf{6 0 0})\end{array}$ & $\mathbf{\%}$ & $\begin{array}{c}\mathbf{1 5 - 6 4} \\
\mathbf{(} \mathbf{0 0 0})\end{array}$ & $\mathbf{\%}$ & $\begin{array}{c}\mathbf{6 5}+ \\
\mathbf{(} \mathbf{0 0 0}\end{array}$ & $\mathbf{\%}$ & Mid-Age \\
\hline 2010 & $7,822.1$ & 27.4 & $19,341.4$ & 67.6 & $1,425.1$ & 5.0 & 26.3 \\
\hline 2020 & $7,780.7$ & 24.0 & $22,445.9$ & 69.2 & $2,214.6$ & 6.8 & 29.9 \\
\hline 2025 & $8,009.5$ & 23.4 & $23,533.4$ & 68.6 & $2,751.3$ & 8.0 & 31.5 \\
\hline 2030 & $8,087.9$ & 22.5 & 24.542 .0 & 68.2 & $3,335.7$ & 9.3 & 33.0 \\
\hline 2035 & $7,893.4$ & 21.1 & 25.606 .1 & 68.5 & $3,889.9$ & 10.4 & 34.5 \\
\hline 2040 & $7,537.2$ & 19.6 & $26,615.6$ & 69.0 & $4,405.1$ & 11.4 & 36.0 \\
\hline
\end{tabular}

Table 2: The Projected Malaysian Population Based on Age, Years 2010-2040 (Source: Department of Statistics Malaysia)

The aging population of Malaysia can also be seen from the structural changes of the population pyramid below. The regressive shape of the pyramid is estimated to remain until 2040. The narrow base of the pyramid indicates that the birth rate is low. The middle part of the pyramid, which is getting broader, indicates that the aging population will significantly increase by 2040 . This population pyramid also projects that the adult mortality rate will decline.

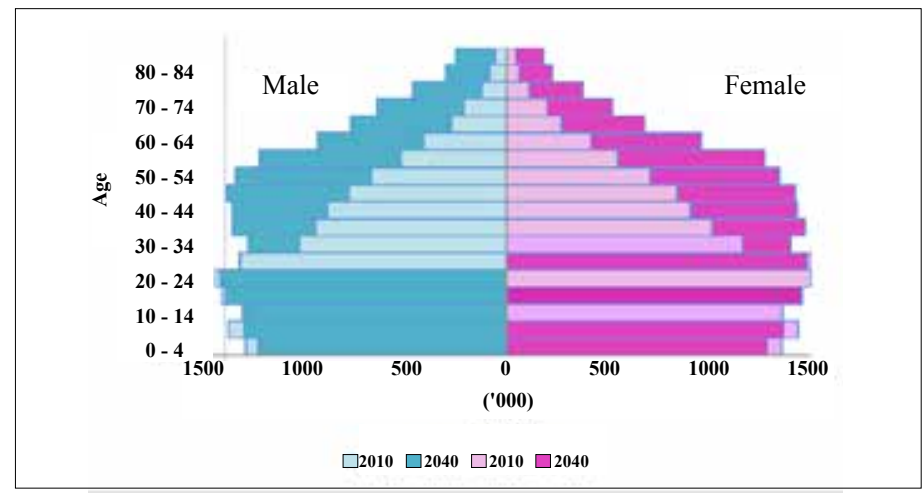

Figure 4: Malaysian Population Pyramid 2010 and 2040

(Source: Department of Statistics Malaysia)

The data depicts that Malaysia will be dominated by an elderly population in the future since fertility and mortality rates are both decreasing. Consequently, 
elderly people are very much dependent upon the working-age population. Therefore, retirement saving and annuity plans for post-retirement age become even more crucial, and the government should begin to plan for the situation.

\section{Conclusion and Policy Recommendations}

This study proposes a structure for retirement annuity plans based on hibah mu'allaqah together with wakalah. The proposed structure allows the TO to offer a Shari'ah-compliant retirement annuity plan with features that resemble those of conventional annuity, mainly the guarantee of regular payout for the participants after their retirement, without in any way violating Shari'ah principles.

The study also examines possible Shari'ah issues which might arise in the operationalisation of the proposed structure, namely the issue of $r i b a$ (interest) via the application of hibah al-thawab, the issue of gharar (uncertainty), the element of maysir (gambling) and the issue of the unfortunate event in the plan. After extensive deliberation, the study concludes that the application of hibah mu 'allaqah in the proposed structure can eliminate these possible Shari' ah issues.

The main challenge in the operationalisation of the structure, however, is not so much about Shari'ah issues; rather, it is the presence of a number of complex operational issues which hinder its operationalisation and its development. The operational issues include, among others, limited long-term investment avenues, (i.e. sukuk), as well as longevity risk.

The study, therefore, recommends an active role for the government in providing the instruments and infrastructure that would support the existence and the development of the plan. One of the initiatives would be the issuance of longterm or perpetual government sukuk.

The study acknowledges the possible gap between the proposed model and commercial viability. Further studies may survey the commercial viability of the proposed model by gathering views from practitioners and experts. In addition, it is suggested that further research should explore and compare various retirement products across jurisdictions, considering the fact that this study relies heavily on the Malaysian setting.

\section{Notes}

* Mohammad Mahbubi Ali is a Research Fellow at the International Institute of Advanced Islamic Studies (IAIS) Malaysia. He can be contacted at mahbubi@, iais.org.my.

** Lokmanulhakim Hussain is a Researcher at the International Shariah Research Academy for Islamic Finance (ISRA). He can be contacted at lokman@isra.my. 
*** Faisal Haroon Zai is the Head of Risk Management, Prudential BSN Takaful Berhad. He can be contacted at faisal.haroon.zai@prubsn.com.my

1. N.A. Kasim, 'Disclosure of Shariah Compliance by Malaysian Takaful Companies,' Journal of Islamic Accounting and Business Research 3, no.3 (2012): 20-38; R. Bekkin, 'Islamic Insurance: National Features and Legal Regulation,' Arab Law Quarterly 21, no. 4 (2007): 3-34.

2. George A. Mackenzie, Annuity Market and Pension Reform (Cambridge: Cambridge University Press, 2006), 54.

3. P. Steel, Pension Matters Your Guide Through the Retirement Income Maze (Housten: Academy Press, 2011), 160.

4. Mackenzie, Annuity Market and Pension Reform, 20.

5. Noor A.Z., 'Hibah Mu'allaqah (Hibah Berta'lik) dan Pelaksanaannya di Dalam Produk Kewangan Islam.' Paper presented at Muzakarah Penasihat Syariah Kewangan Islam 2012 Kali ke 7, Kuala Lumpur, Malaysia, 2012.

6. Muhammad Ismail al-Bukhari, Sahih al-Bukhari (Beirut: Dar Thuq al-Najah, 1422H), hadith no. 2297, 3/96.

7. Abu Abdillah Ahmad ibn Muhammad ibn Hanbal, Musnad al-Imam Ahmad ibn Hanbal (Beirut: Muassasah al-Risalah, 2001), hadith no. 27276, 45/246.

8. Ibid., 246.

9. Ibid., 247.

10. Ibrahim Ali Yusuf Al-Shirazi, Al-Muhadhdhab fi Fiqh al-Imam al-Shafi 'i (Beirut: Dar al-Kutub al-Ilmiyyah, 1995), 246.

11. Ibn Qudamah, Al-Mughni (Cairo: Dar al-Hadith, 2004), 123.

12. Ibid., 123.

13. Ibid., 384.

14. Ibrahim bin Muhammad Ibn Muflih, Al-Mubdi'fi Sharh al-Muqni ' (Beirut: Dar al-Kutub al-'Ilmiyyah, 1997), 196.

15. Accounting and Auditing Organisation for Islamic Financial Institutions, Shariah Standard (Bahrain: AAOIFI, 2015), 679-80.

16. Al-Rassa', Sharh Hudud Ibn 'Arafah (Beirut: Al-Maktabah al-'Ilmiyyah, $1350 \mathrm{H}), 427$.

17. Al-Adawi, Hashiyat al- 'Adawi 'ala Sharh Kifayah al-Thalib al-Rabbani (Beirut: Dar al-Fikr, 1414H), 260.

18. Abu Bakr Muhammad ibn Ahmad Al-Sarakhsi, Al-Mabsut (Beirut: Dar alMa'rifah, 1414H), 141; Malik ibn Anas, Al-Mudawwanat al-Kubra (Beirut: Dar al-Kutub al-Ilmiyyah, 1415H), 382; Yahya ibn Sharaf Al-Nawawi, Minhaj alThalibin (Beirut: Dar al-Fikr, 1425H), 172.

19. Al-Sharbini, Mughni al-Muhtaj (Beirut: Dar al-Kutub al-'Ilmiyyah, 1415H), 573.

20. Al-Adawi, Hashiyat al- 'Adawi, 261.

21. 'Ala' al-Din Ali ibn Sulayman Al-Mardawi, Al-Inshaf fi Ma'rifat al-Rajih min al-Khilaf (n.p: Dar Ihya' al-Turath al-'Arabi, n. d.), 116.

22. Al-Sharbini, Mughni al-Muhtaj, 573.

23. Al-Mardawi, Al-Inshaffi Ma'rifat, 116.

24. 'Ali Haydar Affendi, Durar al-Hukkam fi Sharh Majallat al-Ahkam al-'Adliyyah (Beirut: Dar al-Jil, 1411H/1991), 428. 
25. Ibid., 150.

26. Wizarat al-Awqaf wa al-Shu'un al-Islamiyyah, Al-Mawsu'ah al-Fiqhiyyah alKuwaitiyyah (Kuwait: Wizarat al-Awqaf wa al-Shu'un al-Islamiyyah, 14041427AH), 220.

27. Ibn Rushd, Bidayat al-Mujtahid wa Nihayat al-Muqtashid (Beirut: Dar al-Kutub al-'Ilmiyyah, 2004), 114.

28. Al-Qarafi, Al-Furuq (Beirut: 'Alam al-Kutub, n. d.), 151.

29. Mohammad Akram Laldin, Islamic Legal Maxims and their Application in Islamic Finance (Kuala Lumpur: ISRA, 2013), 114.

30. F. Ismail, 'People on the Move,' Middle East Insurance Review. Available at: http://www.menainsuranceceoclub.com/Article.aspx?id=13821. (Accessed on: 17 March 2014).

31. H. S. Odierno, Z.A. Kassim and S. O. Gonulal, 'Challenges for Takaful going forward,' in Takaful and Mutual Insurance, Alternative Approaches to Managing Risk, ed. E. S. O. Gonulal, (Washington, D.C.: The World Bank, 2012), 129-41.

32. A. Haron, and D. Taylor, 'Risk Management in Takaful,' in Takaful Islamic Insurance: Concepts and Regulatory Issues, ed. S. Archer, R. A. Karim, and V. Nienhaus (Singapore: John Wiley and Sons, 2009), 169-91; Odierno, et al., 'Challenges for Takaful,' 129-41; Ismail, People on the Move,' 1.

33. Ismail, 'People on the Move,' 1.

34. Faizal A. Manjoo, An Appraisal of Longevity Risk: Conventional and Islamic Perspective, ISRA Research Paper 2, (2012), 1-74.

35. Data regarding the remaining bonds of this type was not available.

36. G. Coughlan, 'Longevity Risk and Hedging Solution,' in Handbook of Insurance, Gione Donald (New York: Springer, 2013), 997.

37. Manjoo, An Appraisal of Longevity Risk, 13. 